\title{
APAKAH DANA PIHAK KETIGA DAN TATA KELOLA YANG BAIK DAPAT MENINGKATKAN KINERJA BANK SYARIAH DALAM PERSPEKTIF NASABAH?
}

\author{
Munadiya Nurimani1, Sepky Mardian², Erina Maulidha ${ }^{3}$ \\ Corresponding Author's : Sekolah Tinggi Ekonomi Islam SEBI, Depok, Jawa Barat \\ Email : sepky.mardian@sebi.ac.id
}

\begin{abstract}
Copyright (c) 2022
120

Abstract: This research aims to test the effect of the third-party funds and good corporate governance to the performance of Islamic banks in the customer's perspective. From the customer perspective, the performance of Islamic banks is proxied by the level of profit sharing for depositors. With the positivism paradigm, the sample data of Islamic commercial banks selected based on the availability of governance reports is processed using regression panel data. Fixed effect model is a selected model that is also validated based on the classic assumption test. This research finding can explain that the better the company's governance, the better the performance of Islamic bank. The implementation of effective corporate governance can safeguard the interests of customers and shareholders. This finding further strengthens the argument for the urgency of governance in improving the performance of Islamic banks. But the large level of third-party funds cannot afford to be a control over revenue sharing increases for the investment account holder. This finding has implications that Islamic bank management must be more consistent in implementing effective corporate governance for the benefit of customers and shareholders.
\end{abstract}

Keywords: Third Party Funds, Good Corporate Governance, Banks Performance, Customer Perspective

Abstrak: Penelitian ini bertujuan untuk menguji pengaruh dana pihak ketiga dan tatakelola perusahaan yang baik terhadap kinerja bank syariah dalam perspektif nasabah. Kinerja bank syariah dalam perspektif nasabah yang digunakan adalah tingkat bagi hasil yang diterima nasabah dana pihak ketiga. Dengan paradigma positivisma, data sampel bank umum syariah yang diseleksi berdasarkan ketersediaan laporan tatakelola, diolah menggunakan regresi data panel. Fixed effect model merupakan model terpilih yang juga divalidasi berdasarkan uji asumsi klasik. Temuan riset ini dapat menjelaskan bahwa semakin baik tatakelola perusahaan, maka akan semakin baik kinerja bagi hasil bank syariah. Komitmen penerapan tata kelola yang efektif dapat menjaga kepentingan nasabah dan pemegang saham. Temuan ini semakin memperkuat argumentasi urgensi tatakelola dalam peningkatan kinerja bank syariah. Namun tingkat besarnya dana pihak ketiga tidak mampu menjadi 
kontrol atas peningkatan bagi hasil dana pihak ketiga. Temuan ini memberikan implikasi bahwa manajemen bank syariah harus semakin konsisten dalam menerapkan tatakelola perusahan yang efektif untuk kepentingan nasabah dan juga pemegang saham.

Kata Kunci : Dana Pihak Ketiga, Tatakelola Perusahaan, Kinerja Bank, Perspektif Nasabah

\section{PENDAHULUAN}

Kinerja perusahaan adalah salah satu tema yang sering diteliti, termasuk kinerja bank atau bank syariah. Kinerja tersebut lebih banyak diukur dalam perspektif pemegang saham dan bersifat keuangan. Proksi yang banyak digunakan dalam pengukuran kinerja keuangan tersebut adalah profitabilitas dan efisiensi. Rasio yang sering digunakan adalah return on asset (ROA), return on equity (ROE), ketahanan atas kebangkrutan dengan Tobins $Q$ dan rasio keuangan lainnya (Nomran, N. M. \& Haron, 2020).

Perkembangan industri keuangan, menjadikan keuangan syariah, seperti bank syariah, menjadi salah satu industri yang terus berkembang. Riset atas kinerja bank syariah juga menjadi tema riset. Namun, pengukuran kinerja yang dinilai juga sama dengan bank konvensioal seperti disebutkan sebelumnya.

Perbedaan filosofis bank syariah dan bank konvensional seharusnya menjadikan pengukuran kinerja yang juga berbeda atau paling tidak ada pengembangan perspektifnya.Beberapa peneliti juga merekomendasikan pengukuran kinerja bank syariah yang berbeda seperti kinerja dalam pendekatan syariah, rasio zakat, zakat on assets dan zakat on equity (Nomran, N. M. \& Haron, 2020).

Riset diatas melihat kinerja dalam perspektif fungsi sosial dari bank syariah. Riset ini akan melihat pengukuran kinerja dalam perspektif bank syariah yang lebih mainstream. Bank syariah adalah bank bagi hasil. Fungsi ini seharusnya menjadikan bank syariah juga fokus pada kinerja terhadap penjagaan kepentingan nasabah bagi hasil atau dana pihak ketiga yang menggunakan akad bagi hasil.

Dalam bisnis bank syariah, kepentingan nasabah dana syirkah temporer (DST) menjadi hal yang juga harus mendapat perhatian manajemen sebagai mudharib. Urgensi kinerja ini setidaknya dapat dijelaskan pada beberapa alasan berikut. Pertama, struktur pendanaan bank termasuk bank syariah lebih didominasi oleh dana pihak ketiga, yang berbeda dengan pendanaan non bank. Kedua, meskipun dana DPK lebih tinggi dari modal pemegang saham, tetapi tidak memiliki hak suara dalam Rapat Umum Pemegang Saham (RUPS) sebagai media untuk menjaga kepentingan mereka. Ketiga, berbeda dengan bank konvensional yang pendanaannya menggunakan akad bunga dengan 
imbalan tetap, nasabah bank syariah menggunakan akad bagi hasil yang rentan atas fluktuasi bagi hasil.

Kondisi diatas menjadikan pemegang DST memiliki risiko yang lebih tinggi dibanding perusahaan non bank dan bank konvensional. Dalam perspektif keagenan, masalah keagenan yang muncul menjadi lebih tinggi. Pemegang DST memiliki posisi yang lebih lemah dibanding yang lain. Atas argumen tersebut, sebagai bank syariah, sudah semestinya bank syariah juga memberikan perhatian atas kinerja bagi hasil dalam perspektif nasabah.

Beberapa riset tentang kinerja bagi hasil juga telah dilakukan oleh Farook, Hassan, \& Clinch (2012); Magalhães \& Al-Saad (2013); Rosman et al. (2020); Putri \& Mardian (2020). Penelitian ini akan menguji pengaruh dana pihak ketiga dan tatakelola terhadap kinerja bank syariah dalam perspektif nasabah.

\section{KAJIAN TEORI}

Untuk menjelaskan hubungan antara dana pihak ketiga dan tatakelola terhadap kinerja bank dalam perspektif nasabah, digunakan teori stewardship dan stakeholder.

Teori stewardship berangkat dari perspektif pemikiran akuntansi manajemen yang berdasar pada teoriteori psikologi dan sosiologi. Dalam pengelolaan organisasi, teori ini difokuskan pada harmonisasi antara pemilik modal (principles) dengan pengelola modal (steward) dalam mencapai tujuan bersama. Stewardship theory dalam akuntansi menjelaskan sebuah konstruk pola kepemimpinan dan hubungan komunikasi antara shareholder dan manajemen. Atau dapat pula hubungan antara top manajemen dengan para manajer di bawahnya dalam sebuah organisasi perusahaan (Anton, 2010)

Teori ini dapat menjelaskankan hubungan pemilik dengan pengelola di bank syariah. Dengan adanya dua pihak yang memiliki kepentingan masingmasing namun, tetap harus menge depankan kepentingan bersama.

Teori stakeholder menjelaskan setiap kelompok atau individu yang bisa memengaruhi atau dipengaruhi oleh pencapaian tujuan organisasi. Organisasi itu sendiri harus dianggap sebagai pengelompokkan pemangku kepentingan dan tujuan organisasi harus mengelola minat, kebutuhan, dan sudut pandang mereka (Fontaine, Haarman, \& Schmid, 2018).

Stakeholder adalah semua pihak, internal maupun eksternal, yang dapat mempengaruhi atau dipengaruhi oleh perusahaan baik secara langsung maupun tidak langsung. Dan organisasi memiliki akuntabilitas terhadap stakeholder. Ketika korporasi kuat, maka semakin tinggi korporasi bisnisnya. Sehingga teori stakeholder ialah suatu konsep manajemen strategis yang memiliki tujuan memperkuat korporasi, pengembangan keunggulan kompetitif terhadap pihak eksternal (Nur \& Priantinah, 2012)

Berdasarkan penjelasan di atas, maka dapat disimpulkan teori stakeholder memiliki tujuan untuk 
memperkuat hubungan korporasi. Agar semakin tinggi korporasi bisnis tersebut. Dari praktik Bank Syariah, maka Bank memiliki akuntabilitas terhadap stakeholder, serta memiliki tujuan untuk memperkuat hubungan korporasi yang ada. Sehingga teori ini sangat berpengaruh akan para pemangku kepentingan khususnya demi tercapainya Good Corporate Governance. Dalam praktinya, pada Bank Syariah adanya beberapa pihak yang berkepentingan seperti Dewan Pengawas Syariah (DPS), Komite Audit (KA), Komisaris Independen (KI), Dewan Direksi (DD).

Pada umumnya, kinerja Bank Umum Syariah di Indonesia, diproksikan dengan ROA (Return On Asset) dan ROE (Return On Equity) (Ferial \& Handayani, 2016); metode CAMEL (Chandra, 2016). Pendekatan kinerja tersebut didasarkan pada kepentingan pemegang saham. Penelitian ini akan melihat kinerja bank syariah dalam perspektif nasabah. Kinerja bank dilihat dari tingkat pengembalian pada nasabah atau Return On Invesment Account Holder (RoIAH).

RoIAH merupakan pengukuran dari perspektif deposan (nasabah). Sehubungan Dana Pihak Ketiga lebih dominan daripada pemegang saham. Namun, deposan tidak memiliki wewenang dalam melindungi dananya. Padahal, memiliki risiko yang sama dengan jumlah dana lebih besar dibandingkan pemegang saham. Berbeda dengan Pemegang saham juga, mereka diwakili oleh Dewan direksi dalam melindungi dananya. Sehingga memiliki hak suara atas dana yang ada pada Bank Syariah (Rosman et al., 2020). Maka, jika dari perspektif deposan (nasabah), dapat diukur dengan rumus yang digunakan dalam pengukurannya :

$$
\begin{gathered}
\text { ROIAH }= \\
\frac{\text { Jumlah Hak Pihak Ketiga atas Bagi Hasil }}{\text { Total DPK }}
\end{gathered}
$$

(Farook et al., 2012)

Tatakelola perusahaan (corporate governance) merupakan variabel yang banyak digunakan sebagai faktor pendorong kinerja. Pengukuran tatakelola dapat dilakukan dalam beragam pendekatan atau proksi seperti pengukuran langsung atas prinsip-prinsip tata kelola, nilai self assessment dari manajemen berdasarkan aturan regulasi, atau menggunakan proksi keberadaan para pihak yang terlibat signifikan dalam tata kelola (Ajili \& Bouri, 2018; Grassa \& Matoussi, 2014). Dalam riset ini, model terakhir digunakan sebagai proksi tatakelola yaitu keberadaan dewan pengawas syariah, komisaris independen, komite audit dan dewan direksi.

\section{METODE PENELITIAN}

Penelitian ini menggunakan pendekatan positivisma berupa regresi data panel. Pemilihan sampel dilakukan terhadap bank umum syariah dari 2015-2019 secara purposive sampling dengan menggunakan ketersediaan 
data laporan tahunan dan laporan GCG. Pengolahan data dilakukan atas 30 data yang lengkap dan terbebas dari outlier.

Pemilihan model berdasarkan tahapan data panel berupa Estimasi Model Data Panel, Uji Hausman, Uji Chow, maupun uji Lagrange Multiplier (LM). Model yang terpilih dari pemrosesan diatas adalah fixed effect model (FEM). Selanjutnya model divalidasi dengan pengujian asumsi klasik. Pengujian hipotesis dari model terbaik menggunakan regresi untuk memprediksi pengaruh dana pihak ketiga dan tatakelola terhadap kinerja bank syariah.

Berikut adalah hasil pengolahan data dari model.

Tabel 1

Ringkasan Pengolahan Data

\begin{tabular}{cccc}
$\begin{array}{c}\text { R- } \\
\text { squared }\end{array}$ & $\begin{array}{c}\text { Adjusted } \\
\text { R-squared }\end{array}$ & $\begin{array}{c}\text { F- } \\
\text { statistic }\end{array}$ & $\begin{array}{c}\text { Prob (F- } \\
\text { statistic) }\end{array}$ \\
\hline \multirow{2}{*}{0,793242} & 0.701350 & 8.632295 & 0.000002
\end{tabular}

Sumber: Data diolah (2021)

Tabel 2

Nilai Coefficien dan t-Statistic

\begin{tabular}{cccc}
\hline Variabel & Coefficient & t-Statistic & Prob. \\
\hline DPK & $-0,029593$ & $-2,92936$ & 0,0086 \\
\hline DPS & $-0,001027$ & $-0,12388$ & 0,9027 \\
\hline KI & 0,003986 & 0,67376 & 0,5086 \\
\hline KA & 0,001952 & 0,61907 & 0,5432 \\
\hline DD & 0,000742 & 0,30663 & 0,7625 \\
\hline C & 0,479846 & $3,460,12$ & 0,0026
\end{tabular}

Sumber: Data diolah (2021)

\section{HASIL DAN PEMBAHASAN Pengaruh DPK terhadap Kinerja Bank (RoIAH)}

Berdasarkan hasil pengujian pada Tabel 1 yaitu regresi data panel dengan pendekatan Fixed Effect Model, diperoleh hasil t-hitung adalah sebesar 2,929356. Selain itu, hasil probabilitas ata $\mathrm{p}$ value $t$-statistik yaitu sebesar 0,0086 yang berarti nilai probabilitas tstatistiknya lebih kecil dari 0,05. Dari hasil pengujian ini, maka dapat diambil kesimpulan bahwa terdapat pengaruh signifikan positif antara variabel Dana Pihak Ketiga terhadap Kinerja Bank Umum Syariah (BUS) perspektif Nasabah (ROIAH) periode 2015-2019.

Hasil dari penelitian ini sesuai dengan hipotesis yang diajuakn dalam penelitian bahwa Dana Pihak Ketiga berpengaruh signifikan positif terhadap kinerja Bank Umum Syariah (BUS) perspektif nasabah (ROIAH) periode 2015-2019. Penelitian ini tentu, mendukung teori stewardship bahwa praktik Bank Syariah adanya dua atau lebih pihak yang memiliki kepentingan masing-masing namun, tetap harus mengedepankan kepentingan bersama. Sebagaimana yakni Dana Pihak Ketiga ini, disitu ada kepentingan nasabah, juga Bank selaku pihak principal, menjaga kepercayaan dari pemegang saham dalam menjalankan operasional namun tetap merujuk pada regulasi terkait berdasarkan kepatuhan Syariah.

Penelitian ini mendukung dan memperkuat penelitian yang dilakukan oleh Nursyarifah, (2017), dan Setiawan \& Indriani, (2016) dimana Dana pihak 
ketiga memiliki pengaruh positif signifikan terhadap kinerja Bank Syariah. Sehingga semakin meningkat dana pihak ketiga (DPK), meningkatkan pembiayaan pada Bank Syariah yang berarti meningkatnya kepercayaan masyarakat terhadap Bank Syariah. Semakin meningkatnya kepercayaan masyarakat maka semakin tinggi kinerja Bank Syariah.

Sehingga, Dana Pihak Ketiga yang merupakan dana masyarakat (deposan) yang dihimpun oleh Bank Syariah menjadi tolak ukur kepercayaan masyarakat terhadap Bank Syariah. Maka dari itu, Bank Syariah tidak hanya memenuhi kepentingan pemegang saham yang memiliki tanggungjawab yang sama dengan deposan sebagai penyokong laju operasional Bank Syariah dibandingkan dana ekuitas pemegang saham. Rosman et al., (2020)

Walaupun penelitian ini bertentangan dengan penelitian yang dilakukan oleh Sukmawati \& Purbawangsa, (2016) dan (Fitria \& Widiati, 2018) menyimpulkan bahwa Dana Pihak ketiga berpengaruh tidak signifikan terhadap kinerja Bank Syariah. Dimana Dana Pihak Ketiga tidak memiliki pengaruh karena penghimpunan DPK dialokasikan bukan hanya pada pos pembiayaan, namun pada yang lainnya. Serta dengan perbedaan pengukuran kinerja Bank yang diproksikan dengan ROA, sehingga hasil penelitiannya DPK tidak berpengaruh signifikan terhadap kinerja Bank Syariah.
Dengan demikian secara teoritis dan empiris, telah terbukti bahwa dana pihak ketiga (DPK) memiliki peran yang sangat berpengaruh terhadap kinerja Bank Syariah yang dilihat dari Return On Investment Account Holders (ROIAH). Sehingga dari operasional Bank Syariah tersebut, dengan menghimpun dana pihak ketiga yang kemudian dikembalikan kepada masyarakat dalam bentuk pembiayaan yang optimal hingga mendapatkan keuntungan bagi hasil yang menumbuhkan kepercayaan masyarakat, dan pihak berkepentingan lainnya. Sehingga tercapainya kepentingan bersama.

\section{Pengaruh GCG terhadap Kinerja Bank (ROIAH)}

Berdasarkan hasil pengujian pada Tabel 1 yaitu regresi data panel dengan pendekatan Fixed Effect Model menunjukkan pengaruh yang signifikan secara simultan. Sebagaimana hasil dari nilai Fhitung sebesar 8,632295, yang berarti lebih besar dari 0,05. Berdasarkan hasil penelitian ini, menunjukkan bahwa Dewan Pengawas Syariah, Komisaris Independen, Komite Audit, serta Dewan Direksi secara simultan berpengaruh terhadap kinerja Bank Umum Syariah (BUS). Namun secara parsial, keempat variabel tersebut tidak berpengaruh signifikan. Yang berarti, berdasarkan jumlah proporsi keanggotaan dari Dewan Pengawas Syariah, Dewan Direksi, Komisaris Independen, serta Komite Audit, tidak memiliki pengaruh terhadap kinerja Bank Syariah 
perspektif nasabah. Sebagaimana yang diproksikan dengan Return On Investment Account Holders (ROIAH).

Hasil penelitian ini berbeda dengan hipotesis yang diajukan bahwa Dewan Pengawas Syariah, Komisaris Independen, Komite Audit, dan Dewan Direksi berpengaruh positif terhadap Kinerja Bank Syariah. Hal inipun bertentangan dengan teori stakeholder yang menyatakan bahwa semua pihak internal, maupun eksternal dapat mempengaruhi baik secara langsung maupun tidak langsung. Sehingga dapat tercapainya tujuan memperkuat hubungan korporasi agar Bank Syariah memiliki akuntabilitas terhadap stakeholder, dan pihak-pihak yang memiliki kepentingan. Baik pihak pemegang saham, maupun nasabah yang terkait. Dengan beberapa variabel independent dimana menunjukkan pengaruh GCG terhadap kinerja Bank Syariah. Yang mana diproksikan pada beberapa variabel independent.

\section{Dewan Pengawas Syariah Tidak Berpengaruh Terhadap Kinerja Bank Syariah}

Variabel Dewan Pengawas Syariah dengan diperoleh hasil t-hitung adalah sebesar -0,123884. Selain itu, hasil probabilitas ata $\mathrm{p}$ value $t$-statistik yaitu sebesar 0,9027 yang berarti nilai probabilitas t-statistiknya lebih besar dari 0,05. Dari hasil pengujian ini, maka dapat diambil kesimpulan bahwa tidak terdapat pengaruh signifikan antara variabel Dewan Pengawas Syariah terhadap Kinerja Bank Umum Syariah
(BUS) perspektif Nasabah (ROIAH) periode 2015-2019.

Penelitian ini mendukung penelitian yang telah dilakukan oleh, dan Budiman, (2013), bahwa Dewan Pengawas Syariah tidak berpengaruh terhadap kinerja Bank Syariah. Hal ini menunjukkan karena DPS memiliki rangkap jabatan pada Bank lainnya, yang mengakibatkan kurang fokusnya kinerja seorang DPS dalam mengawasi sebuah Bank Syariah. Sehingga kinerja DPS dinilai kurang baik dan tidak memengaruhi kinerja Bank Syariah.

Adapun hasil penelitian yang dilakukan Eksandy, (2018), dengan penelitian ini. Bahwa, DPS berpengaruh terhadap Kinerja Bank Syariah. Yang berarti semakin banyak anggota maka, memiliki pengaruh besar terhadap peningkatan kinerja Bank Syariah. Dan hasil penelitian Sunarwan, (2015) bertentangan karena dengan pengukuran jumlah rapat DPS tidak membantu tugas DPS dalam hal pengawasan kepatuhan Syariah. Namun, lebih kepada mengikuti regulasi peraturan Bank Indonesia (PBI) Nomor 6/24/PBI/2004. Yakni anggota DPS sekurang-kurangnya berjumlah 2 orang. Dan sebanyakbanyaknya sejumlah 5 orang. Sehingga jumlah anggota tidak dapat menjadi ukuran baik atau tidaknya kinerja Bank Syariah. (Bank Indonesia, 2004)

\section{Komisaris Independen Tidak Berpengaruh Terhadap Kinerja Bank Syariah}

Variabel Komisaris Independen dengan diperoleh hasil t-hitung adalah 
sebesar 0,673755. Selain itu, hasil probabilitas ata $\mathrm{p}$ value $t$-statistik yaitu sebesar 0,5086 yang berarti nilai probabilitas t-statistiknya lebih besar dari 0,05. Dari hasil pengujian ini, maka dapat diambil kesimpulan bahwa tidak terdapat pengaruh signifikan antara variabel Komisaris Independen terhadap Kinerja Bank Umum Syariah (BUS) perspektif Nasabah (ROIAH) periode 2015-2019.

Penelitian ini sejalan dengan Sunarwan, (2015), dan Fransisca W, (2013), bahwa Komisaris Independen tidak berpengaruh terhadap Kinerja Bank Syariah. Dikarenakan dalam implementasinya, Dewan Komisaris yang berasal dari luar perusahaan berdampak kurangnya penegetahuan yang cukup terkait perusahaan. Hal itu juga disebabkan dengan Komisaris Independen tidak memiliki monitoring yang efektif. Padahal Komisaris Independen ialah posisi terbaik untuk melakukan fungsi monitoring agar terciptanya perusahaan yang good corporate governance. Serta sebagai penengah dalam perselisihan yang terjadi antar manajer juga sebagai penasihat dalam mengawasi kebijakan manajemen.

\section{Komite Audit Tidak Berpengaruh Terhadap Kinerja Bank Syariah}

Variabel Komite Audit dengan diperoleh hasil t-hitung adalah sebesar 0,619072 . Selain itu, hasil probabilitas ata $\mathrm{p}$ value $t$-statistik yaitu sebesar 0,5432 yang berarti nilai probabilitas tstatistiknya lebih besar dari 0,05. Dari hasil pengujian ini, maka dapat diambil kesimpulan bahwa tidak terdapat pengaruh signifikan antara variabel Komite Audit terhadap Kinerja Bank Umum Syariah (BUS) perspektif Nasabah (ROIAH) periode 2015-2019.

Penelitian ini sesuai dengan penelitian yang telah dilakukan Fransisca W, (2013), dan Sunarwan, (2015), bahwa penyebab lemahnya akuntabilitas dari struktur perusahaan dalam menegakkan prinsip GCG, salah satu faktornya ialah Komite Audit. Kurangnya pengawasan serta audit eksternal dalam pengendalian audit internal perusahaan. Sehingga disimpulkan bahwa Komite Audit belum optimal dan efektif dalam terlaksananya fungsi Audit internal. Maka dari itu, tidak adanya jaminan keefektifan kinerja Komite Audit dalam pengawasan terhadap kinerja Keuangan Perusahaan.

\section{Dewan Direksi Tidak Berpengaruh Terhadap Kinerja Bank Syariah}

Variabel Dewan Direksi dengan diperoleh hasil t-hitung adalah sebesar 0,306628 . Selain itu, hasil probabilitas ata $\mathrm{p}$ value $t$-statistik yaitu sebesar 0,7625 yang berarti nilai probabilitas $t$ statistiknya lebih besar dari 0,05. Dari hasil pengujian ini, maka dapat diambil kesimpulan bahwa tidak terdapat pengaruh signifikan antara variabel Dewan Direksi terhadap Kinerja Bank Umum Syariah (BUS) perspektif Nasabah (ROIAH) periode 2015-2019.

Hal ini menunjukkan sesuai dengan penelitian Fransisca W, (2013), Sunarwan, (2015) dan Budiman, (2013) bahwa Dewan Direksi dalam 
perusahaan hanya dalam rangka pemenuhan regulasai semata. Sebagaimana berdasarkan UU No.40 Tahun 2007 tentang Perseroan Terbatas (PT) pasal 92 ayat (4) menyebutkan perseroan yang bergerak dibidang menghimpun dan atau mengelola dana masyarakat wajib mempunyai paling sedikit dua orang anggota Direksi. Sehingga Dewan Direksi dalam fungsi manajemen kurang efektif. Hal ini membuktikan bahwa jumlah Dewan Direksi tidak menjamin keefektifan kinerja Bank Syariah. Dan optimalisasi menjalankan tugasnya, karena tergantung kembali pada Bank Syariah masing-masing.

\section{PENUTUP}

Penelitian ini bertujuan untuk mengetahui pengaruh Dana Pihak Ketiga (DPK) dan Tatakelola Perusahaan yang Baik (Good Corporate Governance) terhadap kinerja Dana Pihak Ketiga berpengaruh signifikan negative terhadap kinerja Bank Syariah tahun 2015-2019. Hal ini terbukti dari p value t-statistiknya yaitu sebesar 0,0086 lebih kecil dari 0,05 yang berarti berpengaruh signifikan dan nilai tstatistiknya sebesar -2,929356 yang berarti menunjukkan arah negative.

Tatakelola Perusahaan yang Baik (Good Corporate Governance) berpengaruh signifikan secara simultan dengan dibuktikan nilai F-statistiknya 8,632295 yang berarti lebih besar dari 0,05 . Namun secara parsial (sebagian) tidak berpengaruh signifikan terhadap Kinerja Bank Syariah tahun 2015-2019.
Hal ini dibuktikan dengan $\mathrm{p}$ value $\mathrm{t}$ statistik dari Dewan Pengawas Syariah (DPS) yaitu sebesar 0,9027 yang berarti lebih besar dari 0,05 sehingga Dewan Pengawas Syariah (DPS) tidak berpengaruh signifikan terhadap kinerja Bank Syariah tahun 2015-2019.

Komisaris Independen dengan $\mathrm{p}$ value t-statistik sebesar 0,5086 lebih besar dari 0,05 yang berarti tidak berpengaruh signifikan terhadap kinerja Bank Syariah tahun 2015-2019. Komite Audit dengan p value t-statistik sebesar 0,5432 lebih besar dari 0,05 yang berarti tidak berpengaruh signifikan terhadap kinerja Bank Syariah tahun 2015-2019. Adapun Dewan Direksi dengan $\mathrm{p}$ value $\mathrm{t}-$ statistiknya sebesar 0,7625 lebih besar dari 0,05 yang berarti tidak berpengaruh signifikan terhadap kinerja Bank Syariah tahun 2015-2019.

\section{DAFTAR KEPUSTAKAAN}

Ajili, H., \& Bouri, A. (2018). Corporate governance quality of Islamic banks: measurement and effect on financial performance. Internatio nal Journal of Islamic and Middle Eastern Finance and Management, 11(3), 470-487. https://doi.org/ 10.1108/IMEFM-05-2017-0131

Anton, F. (2010). Menuju Stewardship Theory Manajemen. Majalah Ilmiah Informatika, 1(2), 61-80.

Bank Indonesia. Peraturan Bank Indonesia Nomor : 6/24/PBI/2004 Tentang Bank Umum Yang Melaksanakan Kegiatan Usaha Berdasarkan Prinsip Syariah (2004). 
Budiman, A. (2013). Pengaruh Good Corporate Governance Terhadap Kinerja Keuangan Bank Syariah. Journal of Chemical Information and Modeling, 53(9), 1689-1699.

Chandra, R. (2016). Analisis Kinerja Keuangan Pt Bank Syariah Mandiri Dan Pt Bank Mandiri Tbk Dengan Menggunakan Metode Camel. Jurnal Berkala Ilmiah Efisiensi, 16(2).

Eksandy, A. (2018). Pengaruh Good Corporate Governance Terhadap Kinerja Keuangan Pada Perbankan Syari'Ah Indonesia. Jurnal Akuntansi : Kajian Ilmiah Akuntansi (JAK), 5(1), 1. https://doi.org/ 10.30656/jak.v5i1.498

Farook, S., Hassan, M. K., \& Clinch, G. (2012). Profit Distribution Management By Islamic Banks: An Empirical Investigation. Quarterly Review of Economics and Finance, 52(3), 333-347. https://doi.org/ 10.1016/j.qref.2012.04.007

Ferial, F., \& Handayani, S. R. (2016). Pengaruh good corporate governance terhadap kinerja keuangan dan efeknya terhadap nilai perusahaan (studi pada badan usaha milik negara yang terdaftar di Bursa Efek Indonesia periode 2012-2014). Jurnal Administrasi Bisnis, 33(1), 46-153.

Fitria, L. N., \& Widiati, P. K. (2018). Analisis Pengaruh Rasio Keuangan dan Dana Pihak Ketiga Terhadap Profitabilitas Melalui Financing To Deposit Ratio Sebagai Variabel Intervening Pada Perbankan Syariah. Seminar Nasional Dan Call for Paper: Manajemen, Akuntansi Dan Perbankkan 2018, 679-689.

Fontaine, C., Haarman, A., \& Schmid, S.
(2018). The Stakeholder Theory. American Journal of Case Reports, 19(December), 593-598. https:// doi.org/10.12659/AJCR.909161

Fransisca W, M. (2013). Pengaruh Dewan Direksi, Komisaris Independen, Komite Audit, Kepemilikan Manajerial dan Kepemilikan Institusional Terhadap Kinerja Keuangan. Jurnal Ilmu Manajemen (JIM), 1(1).

Grassa, R., \& Matoussi, H. (2014). Corporate governance of Islamic banks: a comparative study between GCC and Southeast Asia countries. International Journal of Islamic and Middle Eastern Finance and Management, 7(3), 346-362. https://doi.org/https://doi.org/10 .1108/IMEFM-01-2013-0001

Magalhães, R., \& Al-Saad, S. (2013). Corporate Governance In Islamic Financial Institutions: The Issues Surrounding Unrestricted Investment Account Holders. Corporate Governance (Bingley), 13(1), 39-57. https://doi.org/ 10.1108/14720701311302404

Nomran, N. M., \& Haron, R. (2020). A systematic literature review on Sharīah governance mechanism and firm performance in Islamic banking. Islamic Economic Studies, 27(2), 91-123. https://doi.org/ 10.1108/IES-06-2019-0013

Nur, M., \& Priantinah, D. (2012). Analisis Faktor - Fakor yang Mempengaruhi Pengungkapan Corporate Social Responsibility. Jurnal Nominal, 1(1), 17-68.

Nursyarifah, H. O. (2017). Pengaruh DPK, FDR, dan ISR Terhadap Kinerja Keuangan Perbankan Syariah Indonesia Tahun 2010-

10 | Apakah Dana Pihak Ketiga Dan Tatakelola Yang Baik Dapat Meningkatkan Kinerja...... 
2015. Doctoral dissertation, UIN Raden Intan Lampung.

Putri, N., \& Mardian, S. (2020). The Islamic Social Reporting Index and Investment Account Holder in Islamic Banks. Muqtasid: Jurnal Ekonomi Dan Perbankan Syariah, 11(1), 43-54.

Rosman, R., Sharofiddin, A., Banking, I., \& Bank, C. (2020). Protecting the Interest of Profit-Sharing Investment Account Holders in Islamic Banks: The Nigerian Experience. In International Conference on Business and Technology. Springer, Cham. (pp. 1357-1370).

Setiawan, U. N. A., \& Indriani, A. (2016). Pengaruh Dana Pihak Ketiga (DPK), Capital Adequacy Ratio (CAR), dan Non Performing Financing (NPF) terhadap Profitabilitas Bank Syariah dengan Pembiayaan sebagai Variabel Intervening. Diponegoro Journal of Management, 5(4), 1-11.

Sukmawati, N. M. E., \& Purbawangsa, I. B. A. (2016). Pengaruh Pertumbuh an Dana Pihak Ketiga, Pertumbuh an Kredit, Risiko Kredit, Likuiditas dan Kondisi Ekonomi terhadap Profitabilitas. E-Jurnal Manajemen Unud, 5(9), 5398-5432.

Sunarwan, E. (2015). Pengaruh Good Corporate Governance Terhadap Kinerja Keuangan Perbankan Syariah (Studi Kasus pada Bank Umum Syariah dan Unit Usaha Syariah di Indonesia Periode 20102013). Skripsi, UIn Syarif Hidayatullah Jakarta. https://doi. org/10.1377/hlthaff.2013.0625 